\title{
Supplier Selection Decision Support System Drug Wighted Methods Product (WP)
}

\author{
Dina Fanita ${ }^{1}$, Bosker Sinaga ${ }^{2}$ \\ ${ }^{1.2}$ Informatics Engineering Study Program, STMIK Pelita Nusantara, Jl. Iskandar Muda No. 1 \\ Medan, North Sumatra, Indonesia \\ E-mail: dinafanita44@gmail.com,boskersinaga@gmail.com
}

\begin{abstract}
-supplier is very important for companies in services or goods, as well as parts procurement of medicines a Hospital, Hospital GrandMed is one of the largest hospital in Deli Serdang it's important to select suppliers for the procurement of drugs to be maintained and sustained quality of drug availabilitydrug and drug procurement logistics section to selectively choose a supplier with specific criteria so that the process of drug procurement at the Hospital GrandMed running properly and efficiently. The purpose of this study is to develop a decision support system to determine which is the best supplier priority Hospital medicine order so that can always keep the availability of drugs in terms of both the quality of medicines, price and delivery time. Data supplier in view of the historical kesupplier reservations about the company address, price, variants possessed drugs and drug quality and backed by the method of Weighted Product to support the decision which supplier to choose a priority determination. The results of this research program is to create a ranking and determination in the supplier selection GrandMed Hospital.Supplier selection decision support system with Weigthed method GranMed Product Hospital has been able to be built with UML and created with Visual Basic programming language in 2008.
\end{abstract}

Keywords: Customers; Decision Support Systems; WeigthingProduct; Visual Studio 2008

\section{Introduction}

Hospital GrandMed is a company that is currently growing and has reached the summit plenary, the official GrandMed Hospital operates under the auspices of the Foundation Medistra which also has a health education institutions, namely the Academy of Nursing, Midwifery Academy and Institute of Health Medistra,the drug procurement process must Hospital tire GrandMedyak has a relationship with drug suppliers in charge of stockpile medicines and medical equipment, the logistics Hospital GrandMed should prioritize suppliers that are considered best to meet the drug provision of medical supplies assured that from time delivery, quality and price drugs.To overcome this we need a system that helps the process of supplier selection criteria for the appropriate price, delivery time, experience and quality supplier of Supplier drugs.

\section{Theory}

\subsection{Decision Support System}

Decision support system (DSS) is an interactive information system that provides information, modeling, and pemanipulasi data. The system is built to assist decision-making in situations of semi-structured and unstructured situations, where no one knows for sure how the decision should be made (Kusrini, 2017: 15).

\subsection{Supplier}

Supplier or commonly referred to as the Supplier is the parties concerned, more relavan to the success of manufacturing / producers compared to other business, all companies rely on the level of products and services from other businesses to support their ability to serve their customers (David, 2011).

\subsection{Product weight(WP)}

According to Dewi and Yulianto (2018), Weighted Product is one method of solving problems Multiple Attribute Decision Making (MADM). MADM is one method that is capable of taking many criteria and as the basis for the decision maker, and produces subjectively judging involves mathematical assessment. This method was used to evaluate several alternatives to a set of categories or criteria. Product Weighted method using multiplication techniques for connecting branch must be raised to a first criterion weighs the relevant criteria. This process is similar to the process for alternative Ai normalisasi.Prefensi given as follows.

$$
s_{i}=\bigotimes_{j}^{n} x_{i} w_{j}
$$

The formula above is used to normalize the value that will be used. With $i=1,2,3, \ldots, n$. Where $\Sigma w j=1$. Information:

$\mathrm{S} \quad=$ Stating alternative preferences will analogy as a vector $\mathrm{s}$ 


$$
\begin{aligned}
\mathrm{X} & =\text { Stated value criteria } \\
\mathrm{W} & =\text { Stated criteria weights } \\
\mathrm{I} & =\text { Stating the number of criteria } \\
\mathrm{wj} & =\text { Rank is positive for } \\
& \text { advantages and valuable attributes } \\
& \text { negative to attribute costs }
\end{aligned}
$$

Of each alternative relative preferences will be given as follows:

$$
v_{i}=\frac{\otimes_{j}^{n}=1 x_{i} w_{j}}{\bigotimes_{j}^{n}=1(x j \bigotimes)^{w j}}
$$

The above formula is used to find the final value.

With $\mathrm{i}=1,2,3, \ldots, \mathrm{n}$.

Information:

$$
\begin{array}{ll}
\mathrm{V} & =\text { Analogous alternative preferences as a vector } \mathrm{V} \\
\mathrm{X} & =\text { Value criteria } \\
\mathrm{W} & =\text { Weight of criteria or sub-criteria } \\
\mathrm{I} & =\text { Alternative } \\
\mathrm{J} & =\text { Criteria } \\
\mathrm{N} & =\text { Number of criteria } \\
* & =\text { The number of criteria that have been rated on the vector } \mathrm{S},
\end{array}
$$

\section{Analysis}

Tahapanan alisis system starts because of their demand for the new system. In determining Supplier election, it is necessary to Decision Support Systems that are reliable and easy making it easier for companies in decision-making, from the analysis carried out then the data didapatkanlah alternative and criterion in supplier selection Grandmed medicine at the Hospital of Lubukpakam.

The criteria and alternatives of the results of interviews conducted with staff in the drug procurement section in the supplier selection method Granmed Hospital Weight Product (WP) is as follows:

a) Price (C1):

\Menuaskan: 80-100

\Well : 70-79

冈nough : 60-69

$\bigotimes$ Less $:<60$

b) Performance Delivery (C2):

$\triangle$ Kurangdari 1 day: 90

$\otimes 2$ days $\quad: 80$

$\otimes 3$ days $\quad: 70$

冈Lebihdari 3 days : 60

\begin{tabular}{|c|c|c|}
\hline $\begin{array}{l}\text { Supplier } \\
\text { code }\end{array}$ & $\begin{array}{l}\text { name of } \\
\text { Supplier }\end{array}$ & Address \\
\hline 001 & $\begin{array}{l}\text { Sembada Antra } \\
\text { Mitra, PT }\end{array}$ & Jl. Sei Batang Hari 57, Babura Sunggal, district. Sunggal Medan, Medan, North Sumatra 20112 \\
\hline 002 & $\begin{array}{l}\text { Argon grace Medika, } \\
\text { PT }\end{array}$ & JL. Multatuli No. 38, 20151, Hamdan, district. Medan Maimun, Medan, North Sumatra 20212 \\
\hline 003 & Tempo, PT & $\begin{array}{l}\text { Jl. Pelita II, Block A No. 2-4, Kawasan Industri Medan Star, Tj. Morawa B, Tj., Morawa } \\
\text { Tanjung Morawa B, Tanjung Morawa, Deli Serdang Regency, North Sumatra } 20362\end{array}$ \\
\hline
\end{tabular}

c) Variations Drugs (C3):

囚.150 : 90

$\otimes 100-149 \quad: 80$

$\otimes 70-99 \quad: 70$

$\otimes 50-69 \quad: 60$

$\triangle 50 \quad: 50$

d) Distance (C4):

$\triangle 16 \mathrm{KM} \quad: 90$

$\otimes 17-32 \mathrm{KM} \quad: 70$

$\otimes 33-49 \mathrm{KM}: 60$

$\otimes 50 \mathrm{~km} \quad: 50$

Table 1.

alternative Supplier 
Journal of Computer Networks, Architecture and High Performance Computing e-ISSN 2655-9102, Volume 2, No. 1, January 2020, pp 135-139

\begin{tabular}{cll}
\hline $\begin{array}{c}\text { Supplier } \\
\text { code }\end{array}$ & \multicolumn{1}{c}{$\begin{array}{c}\text { name of } \\
\text { Supplier }\end{array}$} & \multicolumn{1}{c}{ Address } \\
\hline 004 & $\begin{array}{l}\text { Pharmindo Anugerah } \\
\text { Lestari, PT } \\
\text { Pharmacies OK }\end{array}$ & $\begin{array}{l}\text { JL.Krakatau, Warehousing and Trading Complex, Block B No. 15-16, Pulo Brayan Darat I, } \\
\text { district. Terrain Tim., Medan, North Sumatra 20236 } \\
\text { Jl. Imam Bonjol 69, Tj. Garbus One, district. Lubukpakam, Deli Serdang, North Sumatra 20 } \\
518\end{array}$ \\
\hline
\end{tabular}

Further steps taken in determining Grandmed Supplier Hospital are as follows:

\subsection{Filling Value Criteria}

Having determined the contents of the value alternative at each alternative Supplier. Value criteria will be made separately for each alternative in order to simplify the process of inputting values as in the following table:

Table 2.

Criteria value of each alternative

\begin{tabular}{cccccc}
\hline No. & name of Supplier & Price & $\begin{array}{c}\text { Delivery } \\
\text { performanc } \\
\text { e }\end{array}$ & Varian Drugs & $\begin{array}{c}\text { Distan } \\
\text { ce }\end{array}$ \\
\hline 001 & Sembada Antra Mitra, PT & 70 & 60 & 60 & 60 \\
002 & Argon grace Medika, PT & 70 & 70 & 70 & 60 \\
003 & Tempo, PT & 80 & 90 & 50 & 90 \\
004 & Pharmindo Anugerah Lestari, PT & 70 & 80 & 80 & 60 \\
005 & Pharmacies OK & 65 & 90 & 90 & 90 \\
\hline
\end{tabular}

\subsection{Weights determine Preference Criteria}

Values preference weights are given as follows:

$\mathrm{W}=5+4+3+2=14$

Where $\Sigma \mathrm{W}=21$

Here below is the calculation of the weight of preference for each criterion:

$$
\begin{aligned}
& C 1=\frac{5}{5 \otimes 4 \otimes 3 \otimes 2}=0: 36 \\
& C 2=\frac{4}{5 \otimes 4 \otimes 3 \otimes 2}=0: 29 \\
& C 3=\frac{3}{5 \otimes 4 \otimes 3 \otimes 2}=0: 21 \\
& C 4=\frac{2}{5 \otimes 4 \otimes 3 \otimes 2}=0: 14
\end{aligned}
$$

Table 3

Weight Value Criteria

\begin{tabular}{clcc}
\hline Code & Assessment criteria & $\begin{array}{c}\text { Weig } \\
\text { ht }\end{array}$ & $\begin{array}{c}\text { improvements } \\
\text { Weight }\end{array}$ \\
\hline C1 & Price & 5 & $0: 36$ \\
C2 & KinerjaPengiriman & 4 & $0: 29$ \\
C3 & Varian Drugs & 3 & $0: 21$ \\
C4 & Distance & 2 & $0: 14$ \\
\hline
\end{tabular}

\subsection{Calculating the Value of Vector}

For the next step is to calculate the vector $\mathrm{S}$, where the data will be multiplied, but previously done reappointment by weight using the following equation:

$\mathrm{Si}=\bigotimes_{j \rrbracket 1}^{n} x_{i j}{ }^{w j} ;$ With $\mathrm{i}=1,2, \ldots \ldots . ., \mathrm{M}$.

a) Sembada Antra Mitra, PT

$=700.36) *(600.29) *(600.21) *(600.14)$

$=2: 36 \times 3: 28 \times 4.62 \times 1.77$

$=63.42$

b) Argon Anugarah Medika, PT

$=(700.36) *(700.29) *(700.21) *(600.14)$

$=2: 44 \times 3: 43 \times 4.62 \times 1.77$

$=68.51$

Dst. , ,

Once the value of vector $\mathrm{S}$ is obtained, the next step is to add up the entire $\mathrm{S}$ to calculate the value of $\mathrm{V}$. The calculation using the following equation: 
$\mathrm{Vi}=\bigotimes_{j \boxplus 1}^{n} x_{i j}{ }^{w j} ;$

$\bigotimes_{j \otimes 1}^{n} \nabla_{j}^{n} \|^{n \nabla^{p j}}$

with $\mathrm{i}=1,2, \ldots, \mathrm{m}$. as follows :

a) AntraMitraSembada, PT

$$
\begin{aligned}
& \frac{63.42}{63.42+68.51+76.25+73.24+80.05} \\
& \frac{63.42}{361.46}=0175
\end{aligned}
$$

b) Anugrah Argon Medical, PT

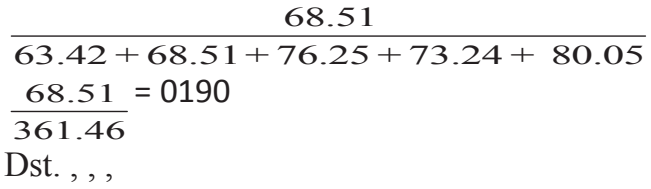

\subsection{Ranking of Alternatives}

After calculation is carried out on ranking results as in the following table:

Table 4

HasilPerangkingan

\begin{tabular}{clc}
\hline Alt & Customer's name & Score \\
\hline 005 & ApotikOke & 0221 \\
003 & Tempo, Pt & 0211 \\
004 & AnugerahPharmindo Lestari, PT & 0203 \\
002 & Argon grace Medika, PT & 0190 \\
001 & AntraMitraSembada, PT & 0175 \\
\hline
\end{tabular}

\section{Design}

The design used using the Unified Modeling Language (UML), namely:

a. Use Case Diagram follows:

The procedure will be described using UML system. Actor or actors are visible in the system are as

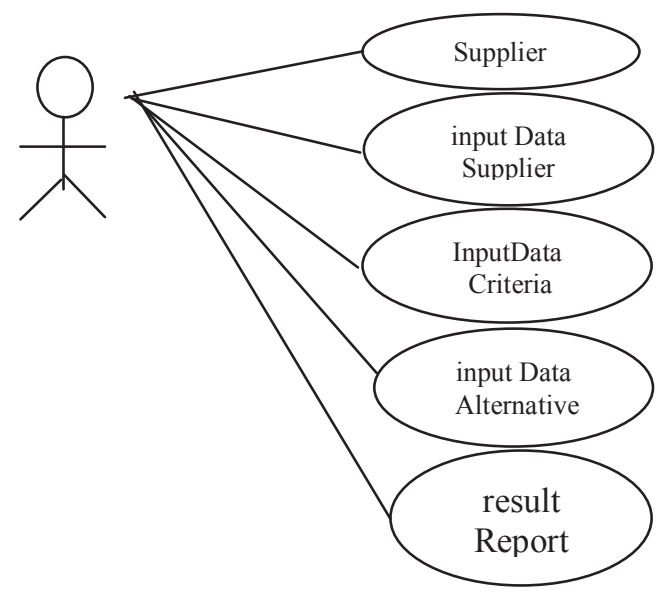

\section{Conclusion}

Picture 1. Use Case Diagram

The conclusions obtained daripenulisan this thesis is as follows:

a) To apply the methods Weight Product (WP) in the selection of medicine at the Hospital Supplier Granmed, first must determine the criteria and determine the value of each alternative, and then determine the weight of the preference criteria, calculate vectors and perform perengkingan from the calculation to get the highest score. 
b) In building the Decision Support Systems election Supplier of medicine at the Hospital Granmed, the first is to design a model system with Unified Modeling Language (UML), design a database table, designing user interfaces and build applications with the software Microsoft Visual Basic 2008 and Microsoft Access 2007 as the database of results SPK construction, the main supplier of choice in accordance with the calculation method of Weight Product (WP) is Pharmacies OK to the value of 0.221 .

\section{Reference}

[1] Alhamidi, 2016. "Perancangan dan Implementasi Sistem Pendukung Keputusan Sistem Pendukung Keputusan untuk mendukung proses Penyeleksian Siswa Baru Pada SMAN 1 Nan Sebaris". Pelita Informatika Budi Dharma, Volume IX No 2 ISSN: 2301-9425.

[2] David, Fred R, 2011. "Strategic Management". Buku 1. Edisi 12 Jakarta

[3] Dewi, C, Yulianto, Y. 2018. "Sistem Penyeleksi Penerima Bantuan Beras Miskin Kauman Kidul Menggunakan Metode Weighted Product Berbasis Mobile". Jurnal Teknik Informatika dan Sistem Informasi Volume 4 Nomor 1.

[4] Kusrini. 20017." Konsep dan Aplikasi Sistem Pendukung Keputusan”. Yogyakarta : Andi

[5] Pramudyo, C.H, Purnomo, D.E.K. 2012. "Perancangan Sistem Pendukung Keputusan Untuk Pemilihan Pemasok Nata De Coco Dengan Metode Simple Additive Weighting". Jurnal Ilmiah Teknik Industri, Vol. 11, No. 1, Juni 2012

[6] Rosa. A.S., dan Shalahuddin. M, 2014 "Rekayasa Perangkat Lunak".Bandung:Informatika,

[7] Sihotang, Hengki Tamando, and Maria Siboro. 2016. "Aplikasi Sistem Pendukung Keputusan Penentuan Siswa Bermasalah Menggunakan Metode Saw Pada Sekolah Smp Swasta Mulia Pratama Medan."Journal of Informatics Pelita Nusantara 1 (1): 1-6.

[8] Widiyanesti, S. 2018. "Penentuan Kriteria Terpenting Dalam Pemilihan Supplier Di Family Business Dengan Menggunakan Pendekatan Analytic Hierarchy Process (Ahp) (Studi Kasus Pada Perusahaan Garmen PT. X). Jurnal Riset Manajemen." 